УДК 159.9. 072

DOI:

Кравчук Світлана Леонтіївна, кандидат психологічних наук, доцент, старший науковий співробітник лабораторії психології спілкування, Інститут соціальної та політичної психології НАПН України, м. Київ, Україна ORCID ID 0000-0002-6951-1912 757kravchuk@gmail.com

\title{
КОНЦЕПТУАЛІЗАЦІЯ ФЕНОМЕНУ ПРОЩЕННЯ В МІЖДИСЦИПЛІНАРНОМУ ДИСКУРСІ
}

\begin{abstract}
Метою дослідження $\epsilon$ концептуалізація прощення як соціально-психологічного феномену, виокремлення критеріїв прощення шляхом аналізу, систематизації та узагальнення наукових поглядів вітчизняних та зарубіжних учених на цей феномен. В емпіричному дослідженні використовувались опитувальник «Шкала прощення як риси характеру» (автори - Дж. В. Беррі, Е. Л. Уортінгтон, Л. Е. О’Коннор, Л. Парротт, Н. Г. Уейд (Berry et al., 2005)); методика «Діагностика депресії та тривоги» (автор - Л. Р. Дерогатіс (Derogatis, 2001)); методика «Діагностика рівня емпатійних здібностей» (автор - Бойко В. В.); методика дослідження соціального інтелекту Дж. Гілфорда (в адаптації О. Михайлової). Зроблено висновок, що феномен прощення є багатовимірним та різнорівневим явищем, яке має багатокомпонентну структуру та містить у собі когнітивний, афективний, конативний, мотиваційний компоненти. Визначено критерії прощення: 1) подолання негативних афектів і суджень щодо кривдника, тобто відмова скривдженої людини від гніву та образи, ненависті, обурення, суму; 2) заміна негативних почуттів до кривдника на більш нейтральні i, нарешті, позитивні, зокрема терпимість, прояви емпатії у вигляді співчуття, співпереживання, милосердя. Доброзичливість до кривдника $є$ позитивним виміром прощення; 3) відмова від мстивої поведінки щодо кривдника; 4) подолання мотивації уникнення щодо кривдника. Прощення може виконувати різні функції, може мати різні умови свого розвитку, різні види, різну модальність, рівні усвідомленості, різні предметні змісти, різний вплив на особу. Натомість непрощення $\epsilon$ більш складним конструктом, ніж просто протилежністю прощення. Так, злочини проти людяності не піддаються прощенню. Здатність до прощення визначається розвиненістю ряду механізмів соціального пізнання (соціального та емоційного інтелекту, емпатії щодо кривдника). Прощення пов'язане з рефлексивною менталізацією, свідомою переробкою і перебудовою свого ставлення до кривдника і ситуації образи. Перспективи подальшого дослідження вбачаються у визначенні низки соціально-психологічних чинників прощення залежно від його предметного змісту, рівня усвідомленості, видів та модальності.

Ключові слова: прощення; депресія; соціальне пізнання; емпатія; соціальний інтелект; помста; непрощення.
\end{abstract}

\section{CONCEPTUALIZATION OF THE FORGIVENESS PHENOMENON IN THE INTERDISCIPLINARY DISCOURSE}

\author{
Svitlana L. Kravchuk, \\ Ph.D. in Psychology, Docent, \\ Senior Researcher of the Laboratory of Psychology of Communication, \\ Institute for Social and Political Psychology, NAES of Ukraine \\ Kyiv, Ukraine \\ ORCID ID 0000-0002-6951-1912 \\ 757kravchuk@gmail.com
}

The aim of the study is to conceptualize forgiveness as a socio-psychological phenomenon, to identify the criteria for forgiveness by analyzing, systematizing, and generalizing the scientific views 
of local and foreign scientists on this phenomenon. The empirical study used the Forgiveness Scale as Character Traits questionnaire by J. W. Berry, et. al; «Diagnosis of depression and anxiety» method by L. R. Derogatis, «Diagnosis of the level of empathic abilities» method by V. V. Boyko, research on social intelligence method by J. Guilford in the adaptation of O. S. Mikhailova. It is concluded that the forgiveness phenomenon is a multidimensional and multilevel phenomenon that has a multicomponent structure and includes cognitive, affective, conative, and motivational components. The criteria for forgiveness are as follows: 1) overcoming the negative emotions and judgments about the offender, that is the refusal of the offended person from anger and resentment, hatred, indignation, sadness; 2) replacement of negative feelings towards the offender with more neutral, and, finally, positive, particularly, tolerance, manifestations of empathy in the form of compassion, empathy, mercy (the benevolence towards the offender is a positive dimension of forgiveness); 3) refusal of vengeful behavior towards the offender; 4) overcoming the motivation to avoid the offender. Forgiveness can perform different functions, can have different conditions of its development, different types, different modalities, levels of awareness, different subject meanings, different impacts on the person. Thus, unforgiveness is a more complex construct than just the opposite of forgiveness. E.g., crimes against humanity are unforgivable. The ability to forgive is determined by the development of a number of social cognition mechanisms (social and emotional intelligence, empathy for the offender). Forgiveness is associated with reflexive mentality, conscious reworking, and restructuring of one's attitude toward the offender and the situation of resentment. The prospect of further research is seen in the identification of different socio-psychological factors of forgiveness depending on its subject content, level of awareness, types, and different modalities.

Keywords: forgiveness; depression; social cognition; empathy; social intelligence; revenge; unforgiveness.

Постановка проблеми. Протягом останніх десятиліть особливої актуальності набуває проблема психічного здоров'я та психологічного благополуччя. Саме в цей період, слід зазначити, здатність до прощення проступків/кривди стає об'єктом дослідницького інтересу у філософії, соціальній психології, психології особистості, у психологічних дослідженнях прикладної спрямованості, зокрема практико-орієнтованого підходу в межах психологічного консультування і психотерапії. Багатьох дослідників цікавлять, зокрема, ефекти терапії прощенням (Enright, \& Fitzgibbons, 2000; Baskin, \& Enright, 2004; Walton, 2005; Elliott, 2011; Worthington, Sandage, 2016; Зливков, \& Лукомська, 2017; Akhtar, Dolan, \& Barlow, 2017). Наразі практикою психотерапії і психологічного консультування доведено, що свідома переробка й перебудова свого ставлення до кривдника і ситуації образи сприяють психологічному благополуччю (Maltby, MacAskill, \& Day, 2001; McCullough, \& Witvliet, 2002; Worthington, \& Sandage, 2016), тоді як неопрацьовані задавнені конфлікти та накопичені «непрошені образи» через проступки/кривди часто стають причиною емоційних розладів, суїцидальних намірів та незадоволеності у сфері спілкування (Sells, \& Hargrave, 1998; Enright, 2001; Мак-Каллоу, 2003; Walton, 2005; Кривцова, 2010; Пуговкина, 2014; Холмогорова, \& Пуговкина, 2015).

У практичній психології вивчення прощення зумовлене важливістю пошуку ефективних шляхів емоційної регуляції. Проте сьогодні концепт «прощення» у психології $\mathrm{\epsilon}$ далеко не однозначним, зокрема щодо розуміння його структури, видів, модальностей, ефектів, соціально-психологічних чинників, рівня усвідомленості. Хто має бути відповідальним за прощення і які дилеми з ним пов'язані?

Наразі в Україні концептуальна розробленість феномену прощення є недостатньою, бракує емпіричних досліджень у цьому напрямі. Вважаємо, що обгрунтування концептуальних засад прощення як соціально-психологічного феномену є актуальним і потребує окремої уваги.

Аналіз останніх досліджень і публікацій. Проаналізувавши наявні дослідження 3 проблеми прощення проступків/кривди, ми згрупували ці дослідження за такими напрямами: 1) фундаментальні та прикладні дослідження в соціальній психології; 2) фундаментальні та прикладні дослідження в психології особистості; 3) дослідження філософської спрямованості; 4) дослідження релігійної спрямованості, зокрема щодо аспектів місіонерськопастирської діяльності; 5) фундаментальні та прикладні дослідження в політичній 
психологіi; 6) фундаментальні та прикладні дослідження в психологіï сім’ї; 7) фундаментальні та прикладні дослідження в психології організації; 8) фундаментальні та прикладні дослідження в психології здоров'я.

Сучасні зарубіжні дослідники розглядають різні сторони здатності до прощення.

Аспекти прощення в релігійному, духовному та філософському контекстах знайшли своє відображення в працях В. Янкелевича (Jankelevitch, 1996), Х. Арендт (Arendt, 1998), Е. Гассін (Гассин, 2003), Ж. Дерріда (Derrida, 2005), П. Рікера (Рикёр, 2004), А. Родіонової (Родионова, 2007), Л. Туссента і К. М. Йоргенсена (Toussaint, \& Jorgensen, 2008), Е. Л. Уортінгтона (Worthington et al., 2010), Д. Томільцевої (Томильцева, 2010), Д. Е. Девіса і X. Янга (Davis et al., 2016) та ін. Вікові і статеві аспекти прощення досліджували Р. Енрайт (Enright, 1996), Дж. Н. Селлз і Т. Д. Харгрейв (Sells, \& Hargrave, 1998), Т. Баскін і Р. Д. Енрайт (Baskin, \& Enright, 2004), А. Чукова (2011), Н. Большунова (2017) та ін. Аспекти зв'язку прощення з емоціями та особистісними властивостями предметно вивчали Т. Баскін і Р. Д. Енрайт (Baskin, \& Enright, 2004), Р. Браун (Brown, 2003), Б. А. Елліот (Elliott, 2011), P. А. Еммонс (Emmons, 2000), А. Чукова (2011), О. Пуговкіна (Пуговкина, 2014), А. Сокур і Е. Носенко (2018) та ін. Особливостям наслідків прощення і непрощення у сфері психічного здоров’я приділяли увагу Р. Д. Енрайт і Р. П. Фіцгіббонс (Enright, \& Fitzgibbons, 2000), Дж. Мак-Каллоу (2003), Л. Тенклова та А. Слезацкова (Tenklova, \& Slezackova, 2016), С. Ахтар, А. Долан і Дж. Барлоу (Akhtar et al., 2017), А. Сокур і Е. Носенко (2018) та ін. Місце прощення в міжособових стосунках вивчали М. Е. Маккаллоу, Е. Л. Уортінгтон, К. С. Рейчел (McCullough, Worthington, \& Cachal, 1997), А. Чукова (Чукова, 2011), Н. Большунова (2017), Б. Баркасса, М. Сальваті, С. Палліні (Barcaccia et al., 2020) та ін.

Феномен прощення розглядають як дію, моральний акт, відповідь, здатність, особистісну диспозицію, особистісний смисл, психічний стан, характеристики соціальних одиниць, прийняття іншого, активне подолання негативної налаштованості щодо кривдника та розвиток щодо нього позитивної налаштованості (Heider, 1958; Wiesenthal, 1969; Smedes, 1984; Jankelevitch, 1996; Enright, 1996; Arendt, 1998; Гассин, 1999; Emmons, 2000; Рикёр, 2004; Baskin, Enright, 2004; Derrida, 2005; Wade, \& Worthington, 2003; Berry, Worthington, O'Connot, \& Wode, 2005; Hall \& Fincham, 2005; Родионова, 2007; Кривцова, 2010; Томильцева, 2010; Чукова, 2011; Большунова, 2017; Lijo, 2018).

Аналіз наукового доробку в означеній сфері досліджень показав, що у вчених наразі немає єдиного погляду щодо концептуалізації феномену прощення.

Мета статті - концептуалізація прощення як соціально-психологічного феномену, виокремлення критеріїв прощення шляхом аналізу, систематизації та узагальнення наукових поглядів вітчизняних і зарубіжних учених на цей феномен.

Виклад основного матеріалу дослідження. Щоб обгрунтувати наукове уявлення про багаторівневий і суперечливий феномен прощення, ми спиралися на розгляд прощення в різних дискурсах, зокрема еволюційному, психологічному, філософському, релігійному. Прощення в міжособистісних стосунках ми розуміємо як процес свідомої відмови особи від образи, гніву, ненависті, обурення, суму, зумовлених несправедливим ставленням інших людей до неї, та заміни негативних почуттів до кривдника більш нейтральними i, нарешті, позитивними, зокрема терпимістю, проявами емпатії у вигляді співчуття, співпереживання, милосердя, що супроводжуються позитивними думками щодо кривдника і припиненням його засудження. Здатність до прощення визначається розвиненістю ряду механізмів соціального пізнання (соціального та емоційного інтелекту, емпатії щодо кривдника).

Наголосимо, утім, що прощення не тотожне забуванню, ігноруванню, потуранню, схваленню і виправданню.

Слід відмітити, що до 1980-х років прощення вивчали переважно в контексті дискурсу релігійної проблематики. У священних текстах більшості світових релігій відображено цінність прощення. П. Рікер зазначає, що мову прощення створено авраамо-християнською культурою, яка являє собою спадщину загальних підходів іудаїзму, християнства та ісламу щодо прощення (Рикёр, 2004). Авраамо-християнська традиція прощення заснована на 
принципі безумовності прощення з боку божественної субстанції. До речі, цей термін використовує Ж. Дерріда для обгрунтування суперечностей безумовного і умовного дару прощення. Дослідник вважає, що прощення є безумовним актом, незалежним від прохання, $\mathrm{i}$ доходить висновку про неможливість «чистого» прощення (Derrida, 2005).

Х. Арендт, розглядаючи прощення, використовує терміни вчинку (Arendt, 1998). На іiі думку, прощення $є$ подвійним феноменом, який належить і публічному простору, і сфері особистого буття. Суперечності знімаються завдяки тому, що в основі подвійності лежить одне уявлення про автора прощення. У розумінні $\mathrm{X}$. Арендт прощення $\epsilon$ не типовою дією, а подією, що розриває каузальну структуру спільності, певним винятком з публічного простору, але необхідним для його існування. Дослідниця вважає, що прощення одного вчинку є можливістю для здійснення нових дій у спільному житті, принципом звільнення від наслідків минулого тієї особи, яка прощає, і тієї, яку прощають, а також різновидом дії зіншими-і-для-іншого. Для Арендт прощення $є$ актом, який залежить від плюральності (plurality) людського буття і який реалізується в спільному житті. Вона зауважує, що без людей, які нас оточують, ми не могли б простити собі ніякого недоліку чи проступку, тому що нам би не вистачало досвіду тієї особистості, заради якої можна простити. Розглядаючи прощення як «чудо» оновлення спільного життя, Арендт, утім, накладає на прощення додаткові обмеження. На іiі переконання, є злочини, які не піддаються ні прощенню, ні покаранню. До таких злочинів відома мислителька відносить злочини проти людяності. Вона виступає проти застосування до воєнних злочинів принципу колективної відповідальності, оскільки він передбачає забуття їхніх акторів. Арендт закликає до колективного осудження конкретних злочинців та до їхньої індивідуальної відповідальності. Разом 3 тим вона переконана, що прощення має реальний політичний дієвий потенціал.

Натомість Ж. Дерріда взагалі ставить під сумнів саму можливість політичного прощення (Derrida, 2005), a B. Янкелевич вважає, що політичне прощення є неспроможним i неприйнятним (Jankelevitch, 1996).

П. Рікер розглядає прощення з позиції питання про самість (Рикёр, 2004). Він аналізує проблему прощення крізь призму пошуку відповідей на питання про суб'єкта-автора прощення і про самість винної особи. Як бачимо, джерелом прощення, на думку Рікера, $\epsilon$ суб'єктність. Дослідник розглядає прощення як константу спільного буття, як важкий акт, але постійно можливий «інкогніто». На його думку, і в тих, хто прощає, і в тих, кого прощають, слід бачити особистостей, яким властиві ознаки самості. Учений розглядає прощення як акт усвідомлення постійної можливості переродження особистості, але водночас вказує на неможливість прощення злочинів проти людяності.

Загалом доречною видається думка Д. Томільцевої щодо акту прощення, що стосуєься вчинків, які не можна простити, тобто щодо яких неможливо навести обставини, що пом'якшують провину, які не піддаються поясненню чи виправданню (Томильцева, 2010). Дослідниця вважає, що за цих умов акт прощення був би руйнівним для чинного соціального порядку.

Цікаво, що і Х. Арендт, і П. Рікер пропонують розглядати прощення як темпоральний перехід від минулої дії до вчинків у теперішньому та можливість для здійснення майбутнього акту. За висловом Арендт, слід прощати для того, щоб діяти далі (Arendt, 1998).

У психології розроблено низку моделей прощення, зокрема: процесуальну (Enright, \& Fitzgibbons, 2000; Baskin, Enright, 2004), еволюційну (McCullough, \& Witvliet, 2002), стрес-ікопінг (Worthington et al., 2000; Strelan, \& Covic, 2006; Harper et al., 2014).

Важливим внеском у розуміння феномену прощення є праці Р. Д. Енрайта (Enright, 1996; 2001). Нам видається надзвичайно цікавим аспектом школи психології прощення Енрайта зв'язок прощення 3 рефлексивною менталізацією, свідомою переробкою i перебудовою свого ставлення до кривдника і ситуації образи (Enright, 2001).

Слід зазначити, що дехто з дослідників розглядає переживання образи як неодмінну умову прощення (Гассин, 1999; Brown, 2003). Е. Л. Уортінгтон (Worthington et al., 2000) 
запропонував метод, який називається REACH (Recall, Empathy, Altruism, commit and hold), для допомоги парам або партнерам. Кроки REACH містять і нагадування про образу.

На думку Р. Д. Енрайта, прощення, як і образа, переживається на трьох рівнях прояву особистості: на рівні афектів (почуттів); на когнітивному рівні суджень і думок; на рівні поведінки (конкретних дій). Дослідник зазначає, що, пробачаючи, скривджена людина, поперше, визнає, що дії кривдника були несправедливими і будуть завжди несправедливими. По-друге, скривджена людина має моральне право на гнів, оскільки будь-яка людина має право на повагу. По-третє, прощення вимагає відмови скривдженої людини від гніву й образи (Enright, 2001).

Зупинімося на розгляді такого важливого аспекту прощення, як відмова скривдженої людини від гніву та образи, ненависті, обурення, суму.

На думку дослідників, прощення передбачає готовність бачити образу і кривдника в більш широкому контексті, а також відпущення негативних переживань, таких як гнів, ненависть, сум, образа тощо (Worthington et al., 2000; VanderWeele, 2018). Так, Дж. Норт вважає, що прощення доцільно розглядати саме як подолання негативних афектів та суджень щодо кривдника (North, 1987).

У дослідженні А. Кононової і О. Пуговкіної позитивне ставлення до прощення і схильність до прощення значуще обернено корелюють 3 вираженістю симптомів тривоги, соціального дистресу та уникнення (Кононова, \& Пуговкина, 2018). Щоб оцінити схильність i настановлення щодо прощення, вони використовували опитувальник «Схильність до прощення і настановлення щодо прощення проступків» - Tendency to Forgive Scale (TTF) and Attitudes Toward Forgiveness (ATF) (Brown, 2003).

У низці інших досліджень також виявлено обернену кореляцію між прощенням i тривогою, соціальним дистресом, уникненням, депресією, а також факторами ризику виникнення тривоги i депресії, зокрема негативною афективністю й нейротизмом (Worthington et al., 2000; Thompson et al., 2005; Marks, Trafimov, Busche, \& Oates, 2013). Чим більше учасники дослідження виявляли доброзичливість і прощення, тим менше вони потерпали від депресивної симптоматики (Barcaccia et al., 2020).

Щоб перевірити гіпотезу про наявність значущого оберненого кореляційного зв’язку між прощенням і вираженістю симптомів тривоги й депресії, ми провели у 2019-2020 роках відтворювальне дослідження. Його учасниками стали 168 осіб, зокрема 87 жінок і 81 чоловік: 96 студентів віком від 19 до 23 років, які здобувають першу вищу освіту, і 72 студенти віком від 24 до 45 років, які здобувають другу вищу освіту. Вибірку респондентів було сформовано на базі п'яти українських університетів: Київського університету імені Бориса Грінченка, Національного педагогічного університету імені М. П. Драгоманова, Університету економіки і права «КРОК», Київського національного лінгвістичного університету, Київського національного університету імені Тараса Шевченка. Участь у дослідженні була повністю добровільною. Для опитування респондентів протягом 2020 року використовувалася мережа Інтернет. У будь-який момент учасники могли відмовитися від подальшої участі в дослідженні. Збирання даних проводилося на основі анонімності.

Ми застосовували під час дослідження такі психодіагностичні методи: 1) опитувальник «Шкала прощення як риси характеру» (автори - Дж. В.Беррі, Е. Л. Уортінгтон, Л. Е. О’Коннор, Л. Парротт, Н. Г. Уейд (Berry et al., 2005)); 2) методику «Діагностика депресії та тривоги» (автор - Л. Р. Дерогатіс (Derogatis, 2001)).

Емпірично виявлено негативні значущі кореляційні зв'язки показника схильності до прощення за коефіцієнтом кореляції Ч. Спірмена 3 депресією $(p=-0,37 ; \mathrm{p}<0,01)$ і тривогою $(p=-0,34 ; \mathrm{p}<0,01)$. Також ми застосували простий лінійний регресійний аналіз для перевірки гіпотези про схильність до прощення як предиктора зниження депресії (табл.). Виявлено, що схильність до прощення як незалежна змінна має статистично значущий негативний стандартизований коефіцієнт Бета (відповідно, -0,425). Отримані дані свідчать про те, що схильність до прощення $є$ предиктором зниження депресії. 
Коефіцієнти за простим лінійним регресійним аналізом

\begin{tabular}{|c|c|c|c|c|c|}
\hline \multirow{2}{*}{ Модель } & \multicolumn{2}{|c|}{$\begin{array}{l}\text { Нестандартизовані } \\
\text { коефіціснти }\end{array}$} & \multirow{2}{*}{$\begin{array}{c}\text { Стандартизовані } \\
\text { коефіціснти } \\
\text { Бета }\end{array}$} & \multirow{2}{*}{$\mathbf{t}$} & \multirow{2}{*}{$\begin{array}{c}\text { Рівень } \\
\text { значущості }\end{array}$} \\
\hline & B & $\begin{array}{c}\text { Стандартна } \\
\text { помилка }\end{array}$ & & & \\
\hline Константа & 15,205 & 0,425 & & 35,740 & 0,000 \\
\hline $\begin{array}{l}\text { Схильність } \\
\text { до прощення }\end{array}$ & $-0,360$ & 0,042 & $-0,425$ & $-8,507$ & 0,000 \\
\hline
\end{tabular}

Примітка. $\mathrm{R}=0,667 ; \mathrm{R}^{2}=0,445 ;$ Adjusted $\mathrm{R}^{2}=0,437 ; \mathrm{F}=5,445, \mathrm{p}<0,05$

Завдяки низці зарубіжних досліджень показано, що інтервенції, засновані на прощенні, сприяють зменшенню вираженості симптомів депресії, тривожності та покращенню показників суб'єктивного психологічного благополуччя, зокрема підвищенню оптимізму, поліпшенню навичок розв'язання конфліктних ситуацій (Berry et al., 2005; Ricciardi et al., 2013; Akhtar et al., 2017). Результати деяких досліджень відбили значущий обернений зв'язок між прощенням і ворожістю, критичністю й недовірою (Tenklova, \& Slezackova, 2016).

А. Кононова та О. Пуговкіна виявили значущий обернений зв'язок між позитивним ставленням до прощення і схильності до прощення і макіавеллізмом як особистісною рисою, а також вибором залежних та агресивних відповідей у комунікативних ситуаціях. Досить цікавим виявився той факт, що агресивні і залежні реакції в комунікативних ситуаціях потрапили в одну групу, значуще обернено пов'язану зі схильністю до прощення. Менш схильні прощати як респонденти 3 вибором агресивних реакцій, так і респонденти, що віддають перевагу залежному стилю. А. Кононова та О. Пуговкіна вважають, що обернений зв'язок із залежним стилем можна пояснити наявністю ланцюжка хронічного міжособистісного дискомфорту, пов'язаного 3 «проковтуванням образ» i водночас демонстрацією зовнішньої толерантності (Кононова, \& Пуговкина, 2018).

Р. Х. Аль-Мабук, Р. Д. Енрайт і П. А. Кардіс зазначають, що завдяки прощенню людина долає негативний афект (зокрема обурення), різкі судження і негативну поведінку (зокрема пошук помсти) щодо особи, яка спричинила кривду, і замінює їх на більш позитивний афект, позитивні думки й позитивну поведінку (Al-Mabuk, Enright, \& Cardis, 1995). Як бачимо, подолання негативних афектів і суджень щодо кривдника, тобто відмова скривдженої людини від гніву та образи, ненависті, обурення, суму, постає як один 3 критеріїв прощення. Так само Р. Д. Енрайт (Enright, 2001) та Е. Гассін (Гассин, 1999) вважають, що прояв прощення в міжособистісних стосунках передбачає не тільки рішення відмовитися від негативних думок, емоцій і поведінкових проявів щодо кривдника, котрий незаслужено образив особу, а й заохочення до позитивних думок, поведінкових проявів та емоцій щодо того ж кривдника.

Зупинімося на розгляді такого аспекту прощення, як заміна негативних почуттів до кривдника на більш нейтральні, $i$, нарешті, позитивні. У низці досліджень підтверджується, що завдяки прощенню відбувається заміна негативних почуттів на терпимість і співчуття (Raj, Elizabeth, \& Padmakumari, 2016). Позитивний значущий зв'язок між прощенням i проявами емпатії у вигляді співчуття й милосердя виявив Р. Д. Енрайт (Enright, 2001). Цікавим у цьому контексті є також дослідження Е. В. Хілла 3 колегами, які простежили позитивний значущий зв'язок прощення з емпатією та емоційним інтелектом (Hill, Allemand, $\&$ Burrow, 2010). Цей зв'язок підтверджено низкою інших зарубіжних досліджень (Worthington, Witvliet, Pietrini, \& Miller, 2007; Tenklova, \& Slezackova, 2016).

Щоб перевірити гіпотезу щодо наявності значущого прямого кореляційного зв'язку прощення з емпатією, протягом 2019-2020 років ми провели відтворювальне дослідження. У 
ньому взяли участь 224 особи (116 жінок і 108 чоловіків): 132 студенти віком від 19 до 23 років, які здобувають першу вищу освіту, та 92 студенти віком від 24 до 45 років, які здобувають другу вищу освіту. Вибірку респондентів було сформовано, як уже зазначалося вище, на базі п’яти вітчизняних українських університетів. Участь респондентів у дослідженні була також конфіденційною і добровільною.

Ми використали такі психодіагностичні методи: 1) методику «Діагностика рівня емпатійних здібностей» (автор - Бойко В. В.); 2) опитувальник «Шкала прощення як риси характеру» (автори - Дж. В. Беррі (J. W. Berry), Е. Л. Уортінгтон (Е. L. Worthington), Л. Е. O’Коннор (L. Е. O’Connor), Л. Парротт (L. Parrott), Н. Г. Уейд (N. G. Wade)) (Berry et al., 2005).

Результати нашого відтворювального дослідження відбили позитивні значущі кореляційні зв'язки за коефіцієнтом Ч. Спірмена показника схильності до прощення 3 емоційним каналом емпатії $(p=0,41 ; \mathrm{p}<0,01)$, раціональним каналом емпатії $(p=0,39 ; \mathrm{p}<$ $0,01)$, інтуїтивним каналом емпатії $(p=0,362 ; \mathrm{p}<0,01)$ та проникальною здатністю в емпатії $(p=0,37 ; \mathrm{p}<0,01)$. Отже, людям з більш високим рівнем емпатії легше прощати інших.

Говорячи про зв'язок прощення з емпатією, слід враховувати проблему механізмів соціального пізнання. Сьогодні зростає дослідницький інтерес до концепції соціального пізнання та здатності до прощення як одного з часткових проявів соціального пізнання. Особливий інтерес становлять погляди Р. Д. Енрайта: позитивний ефект прощення дослідник пов'язує не 3 уявленням про прощення як про благо чи цінності, а 3 безпосередньою «роботою прощення», 3 опорою на емпатію і рефлексивну складову соціального пізнання (Enright, 1996). Енрайт вважає, що адаптивний характер здатності до прощення визначається якістю процесів соціального пізнання, зокрема рефлексивною менталізацією.

У межах «третьої хвилі» когнітивно-біхевіорального підходу здатність до прощення розглядають як диспозиціональну рису, частковий вияв механізмів і водночас результат соціального пізнання індивіда, оскільки здатність до прощення грунтується на здатності усвідомлювати власні емоції і керувати ними, а також на здатності і готовності проявляти емпатію щодо кривдника (Mullet, \& Girard, 2000; Berry et al., 2005). До речі, у когнітивній моделі прощення М. Маккаллоу також відображено зв'язок між прощенням і соціальною перцепцією (McCullough et al., 2013).

Н. Большунова (2017), яка аналізувала дослідження зв'язку між прощенням у молодших школярів та підлітків і рівнем їхнього соціального інтелекту (за Дж. Гілфордом), виявила значущі позитивні кореляції, які свідчать про те, що більш високий рівень готовності до прощення співвідноситься з більш високим рівнем соціального інтелекту.

Протягом 2019 року ми провели відтворювальне дослідження, щоб перевірити гіпотезу про значущий позитивний зв'язок між схильністю до прощення і соціальним інтелектом. Його учасниками стали 236 осіб - 120 жінок і 116 чоловіків: 128 студентів віком від 19 до 23 років, які здобувають першу вищу освіту, та 108 студентів віком від 24 до 45 років, які здобувають другу вищу освіту. Вибірку респондентів було сформовано на базі п'яти вже згаданих університетів. Респонденти проходили опитування очно. Їхня участь у дослідженні була конфіденційною та добровільною.

Ми використовували такі психодіагностичні методи: 1) методику дослідження соціального інтелекту Дж. Гілфорда (в адаптації О. Михайлової); 2) опитувальник «Шкала прощення як риси характеру» (автори - Дж. В. Беррі (J. W. Berry), Е. Л. Уортінгтон (E. L. Worthington), Л. Е. O’Коннор (L. Е. O’Connor), Л. Парротт (L. Parrott), Н. Г. Уейд (N. G. Wade)) (Berry et al., 2005).

Результатом нашого дослідження стало виявлення позитивних значущих кореляційних зв'язків за коефіцієнтом кореляції Ч. Спірмена показника схильності до прощення із субтестом 3 «Вербальна експресія» $(p=0,36 ; \mathrm{p}<0,01)$, композитною оцінкою $(p$ $=0,34 ; \mathrm{p}<0,01)$, субтестом 4 «Історії 3 доповненням» $(p=0,33 ; \mathrm{p}<0,01)$, субтестом 2 «Групи експресії» $(p=0,32 ; \mathrm{p}<0,01)$ та субтестом 1 «Історії із завершенням» $(p=0,31 ; \mathrm{p}<0,01)$. 
Отримані результати свідчать про те, що особи з більш вираженим соціальним інтелектом більшою мірою схильні прощати.

До речі, досить цікавий факт було виявлено завдяки дослідженню А. Кононової та О. Пуговкіної: шкали позитивного ставлення до прощення і схильності до прощення відбивають значущий прямий зв'язок з наданням переваги компетентному стилю реагування в ситуаціях спілкування (Кононова, \& Пуговкина, 2018). У контексті філософського підходу Д. Томільцева розглядає прощення як досвід відновлення міжособистісних стосунків (Томильцева, 2010). Багато хто 3 дослідників схильність до прощення пов'язує 3 просоціальною спрямованістю особистості, а також зі схильністю до співробітництва, емоційною стабільністю (Berry et al., 2005; Thompson et al., 2005; McCullough et al., 2013).

Зв'язок просоціальної спрямованості особистості 3 прощенням досліджувала Н. Большунова (2017). На іï думку, визнання іншого Іншим відкриває можливості для діалогу, під час якого той, хто прощає, і той, кого прощають, здатні почути одне одного, можуть відгукуватися на висловлювання одне одного, сприймати і розуміти стани одне одного, зокрема стани переживання образи, болю, каяття тощо. Згідно з Н. Большуновою, визнання іншого Іншим, і справжній діалог, і співчуття, і чуйність одне щодо одного можливі, якщо вони опосередковані загальною аксіологічного мірою, «вищим третім», соціокультурними зразками, які ми розуміємо як композицію цінностей, властиву певному типу культури, з якими людина (у цій ситуації - учасники діалогу) співвідносить свої дії, вчинки, переживання, вибори і рішення. Дослідниця наголошує на тому, що і від того, хто здатний просити прощення, визнавати свою провину, вимагається здатність визнання іншості Іншого, готовність до діалогу, до співчуття, наявність достатньо зрілого соціокультурного самовизначення. На думку Большунової, можливість прощення в повсякденних, життєвих ситуаціях виникає перш за все в умовах діалогу і відгуку на інтенції у ставленні одне до одного, а також за умови залучення того, хто прощає, і того, кого прощають, у сферу загальних смислів, цінностей, соціокультурних зразків.

До речі, дехто 3 дослідників вважає, що важлива умова прощення кривдника - це «відділення» його як особистості від скоєного ним проступку (Fincham, 2000; Ross, Rachel, Boon, \& Stackhouse, 2018). Так, згідно з процесуальною моделлю прощення (Enright, \& Fitzgibbons, 2000), цей процес охоплює чотири основні стадії: 1) виявлення, коли людина намагається зрозуміти, якою мірою заподіяна образа ущемляє ії гідність і веде до шкідливих наслідків; 2) рішення, коли людина визначає для себе сенс прощення і приймає рішення взяти на себе зобов'язання щодо прощення відповідно до свого розуміння; 3) робота, спрямована на досягнення когнітивного розуміння $i$ зміни сприйняття кривдника, себе $i$ взаємин з кривдником; 4) поглиблення, завдяки якому скривджена особа знаходить сенс у стражданні і прощенні, що приводить до зменшення негативних емоцій та оновлення життєвих цілей.

Як бачимо з проведеного вище аналізу, одним із критеріїв прощення $є$ заміна негативних почуттів до кривдника більш нейтральними i, нарешті, позитивними, зокрема терпимістю, проявами емпатії у вигляді співчуття, співпереживання, милосердя. Доброзичливість у цьому контексті є позитивним виміром прощення.

Звернімо особливу увагу на один з видів прощення, виокремлений Р. Д. Енрайтом, прощення, засноване на помсті: я можу простити кривдника, тільки якщо я покараю його тією мірою, яка пропорційна моєму власному стражданню (Enright, 2001).

A тепер запитаймо: чи може бути прощення, засноване на помсті? На нашу думку, в основі прощення і помсти лежать принципово різні мотивації.

Прагнення помсти і здатність прощати є універсальними психологічними характеристиками людей (McCullough, \& Witvliet, 2002; McCullough et al., 2013). Дж. К. Карреманс, П. А. Ван Ланге, Дж. У. Оуверкерк та Е. С. Клувер зазначають, що прощення можна концептуалізувати під кутом зору трансформації мотивації, оскільки це передбачає більш широкі міркування, такі як прагнення до благополуччя у взаємовідносинах чи бажання сприяти як власному благополуччю, так і благополуччю партнера (Karremans, Vanlange, 
Ouwerkerk, \& Kluwer, 2003). М. Е. Маккаллоу, Е. Л. Уортінгтон і К. С. Рейчел використовували визначення прощення, яке відповідає концепції трансформації мотивації. Зокрема, дослідники визначають прощення як сукупність мотиваційних змін, завдяки яким людина стає: 1) дедалі все менш мотивованою до помсти, що порушує стосунки з партнером; 2) усе менш мотивованою зберігати відчуження від кривдника та 3) все більш мотивованою до примирення та доброзичливості щодо кривдника, незважаючи на його кривдні дії (McCullough et al., 1997).

Важливим внеском у розуміння феномену прощення стали праці Ф. Гайдера (Heider, 1958). На думку дослідника, прощення доцільно розглядати як вибір індивідуума відмовитися від мстивої поведінки.

М. Е. Маккаллоу, Р. Курзбан і Б. А. Табак пропонують визначати помсту і прощення у функціональному плані, що дасть змогу розглядати ці два концепти під кутом зору еволюційного підходу. Дослідники вважають, що і помста, і прощення породжуються еволюційним добором, тобто помста і прощення є різними поведінковими адаптаціями, які розв’язують конкретні адаптаційні проблеми, а саме: помста еволюціонувала для запобігання шкоді/кривді в майбутньому, а прощення має на меті збереження цінних стосунків, незважаючи на певну шкоду/кривду (McCullough et al., 2013). Е. Л. Уортінгтон, аналізуючи прощення, дійшов висновку, що відмова від помсти часто є основним складником прощення (Worthington, \& Sandage, 2016). К. Дж. Ліджо зазначає, що прощення забороняє помсту i спонукає до сильних позитивних емоцій, заснованих на любові (Lijo, 2018). До речі, у низці досліджень показано зв'язок непрощення з бажанням помсти чи уникненням кривдника (Wade, \& Worthington, 2003).

У цьому контексті на особливу увагу заслуговує дослідження М. Маккаллоу та його колег, згідно з яким прощення $є$ процесом просоціальної трансформації міжособистісної мотивації щодо кривдника, коли мотивація стає менш мстивою, менш уникною і більш доброзичливою (McCullough et al., 2013). Отже, відмова від мстивої поведінки є одним із критеріїв прощення.

Особливого значення, коли йдеться про аналіз феномену прощення, набуває виокремлення певних його видів. Дослідники розглядають такі два типи прощення: епізодичне прощення, яке стосується певної провини конкретного кривдника, і схильність до прощення як відносно стабільну рису, або здатність прощати (Emmons, 2000; Mullet, Girard, 2000; Berry et al., 2005). Дж. В. Беррі, Е. Л. Уортінгтон, Л. Е. О’Коннор, Л. Парротт, Н. Г. Уейд вважають, що прощення є диспозиціональною рисою особистості (Berry et al., 2005). Р. Еммонс розглядає прощення як особистісний конструкт високого рівня, коли особа має такі характеристики: спроможність бути сприйнятливою до обставин, які зменшують гнів; володіння навичками контролювати емоції; емпатія; смиренність; доброзичливість і прагнення перебувати в гармонійних стосунках (Emmons, 2000). Е. Л. Уортінгтон використовує терміни «прощення, засноване на рішенні» та «емоційне прощення», щоб описати різні способи прощення (Worthington, \& Sandage 2016). Дехто 3 дослідників виокремлює прощення як більш чи менш усвідомлений процес прийняття рішення та емоційне прощення, що відбувається практично неусвідомлено (Davis et al., 2015).

Зазвичай розглядають три контексти прощення: прощення іншої людини, прощення себе та прощення ситуації чи обставин (Lijo, 2018). Прощення може бути спрямоване на різні об’єкти. Можна пробачити іншим людям, собі або навіть ситуації, яка не залежить від обставин власного життя. Так, дехто з дослідників вважає, що прощення застосовується не лише до окремих людей, але також до ситуацій, зокрема стихійних лих, таких як землетрус, торнадо, повені, або катастроф в особистому житті, наприклад смерті значущої людини або хронічних захворювань. Ці ситуації викликають у людей гнів і безнадійність (Thompson et al., 2005).

Самопрощення визначають як процес звільнення від образи на себе за сприйнятий проступок чи неправоту (Macaskill, Maltby, \& Day, 2002). Л. Бауер, Дж. Даффі та Е. Фоунтейн вважають, що самопрощення є переходом від самовідчуження до відчуття 
узгодженості власного «Я», розуміння того, що ідеальних людей немає і кожній людині властиво помилятися (Bauer, Duffy, \& Fountain, 1992). Прощення самого себе - це найбільш напружена форма прощення. У певних ситуаціях люди відчувають гнів на себе, коли будьяка їхня поведінка - вербальна чи невербальна - призводить до значних саморуйнувань чи наслідків, що не піддаються корекції.

Цікаві міркування висловили Дж. Х. Голл та Ф. Д. Фінчем: важче жити без самопрощення, ніж без прощення інших. На думку дослідників, причина полягає в тому, що відмова від самопрощення завдає шкоди самій людині, зокрема призводить до депресії та самогубства, а непрощення інших впливає лише на зовнішню позитивну взаємодію та адаптацію (Hall, \& Fincham, 2005). Результати низки досліджень підтвердили, що самопрощення знижує ризик виникнення симптомів посттравматичних розладів i суїцидальних намірів (Lijo, 2018).

Слід зазначити, що в прощзенні значну роль відіграє каяття з боку кривдника. Дослідники виявили, що для ображених осіб прощення кривдників без каяття з їхнього боку призводить до певних негативних наслідків, зокрема відмови від легітимних вимог справедливості і відплати, зниження самооцінки, втрати контролю над ситуацією, збереження й надалі поганого ставлення до себе, підкріплення поведінки кривдника, а також збільшення ймовірності такої небажаної поведінки в майбутньому (Enright, \& Fitzgibbons, 2000; Enright, 2001).

П. Рікер вважає, що передумовою для прощення винного є усвідомлення ним своєї провини. У герменевтичній феноменології Рікера у зв'язку із прощенням постає питання про відповідальність за дії (Рикёр, 2004). На думку дослідника, умовою прощення з боку тих, хто прощає, є визнання винною особою відповідальності за власні вчинки.

Практична і соціальна значущість дослідження. Практичне і соціальне значення дослідження полягає в тому, що отримані результати можуть бути використані в процесі подальшого дослідження проблеми прощення та в психологічній консультації і психотерапії.

Висновки та перспективи подальших досліджень. Проблематика концептуалізації феномену прощення в міждисциплінарному дискурсі виводить нас у площину певних, на нашу думку, принципово значущих, тез.

Феномен прощення $\epsilon$ багатовимірним та різнорівневим явищем, що має багатокомпонентну структуру та містить у собі когнітивний, афективний, конативний i мотиваційний компоненти.

Критеріями прощення є:

- подолання негативних афектів та суджень щодо кривдника, тобто відмова скривдженої людини від гніву та образи, ненависті, обурення, суму;

- заміна негативних почуттів до кривдника більш нейтральними i, нарешті, позитивними, зокрема терпимістю, проявами емпатії у вигляді співчуття, співпереживання, милосердя. Доброзичливість до кривдника є позитивним виміром прощення;

- відмова від мстивої поведінки щодо кривдника;

- подолання мотивації уникнення щодо кривдника.

Прощення може виконувати різні функції, може мати різні умови свого розвитку, різні види, різну модальність, рівні усвідомленості, різні предметні змісти, різний вплив на особу.

Непрощення є більш складним конструктом, ніж просто протилежністю прощення. Злочини проти людяності не піддаються прощенню.

Здатність до прощення визначається розвиненістю ряду механізмів соціального пізнання (соціального та емоційного інтелекту, емпатії щодо кривдника). Прощення пов'язане 3 рефлексивною менталізацією, свідомою переробкою і перебудовою свого ставлення до кривдника і ситуації образи.

Перспективи подальших досліджень вбачаємо у визначенні низки соціальнопсихологічних чинників прощення залежно від його предметного змісту, рівня усвідомленості, видів та модальності. 


\section{Список використаних джерел}

Большунова, Н. Я. (2017). Прощение как духовно-нравственное явление и психологический феномен. Человек и мир, 1 (1), 201-218.

Гассин, Э. А. (1999). Психология прощения. Вопросы психологии, 4, 93-104.

Гассин, Э. (2003). Православие и проблема прощения. Московский психотерапевтический журнал, 3, 166-186.

Зливков, В. Л., \& Лукомська, С. О. (2017). Прощення інших і прощення себе в контексті подолання особистістю кризових ситуацій. Теоретичні і прикладні проблеми психологї, 2, 103-112.

Кононова, А. П., \& Пуговкина, О. Д. (2018). Валидизация опросника «Склонность к прощению и установки по отношению к прощению проступков» на российской выборке. Консультативная психология и психотерапия, 26 (4), 27-45. doi: 10.17759/срp.2018260403.

Кривцова, С. В. (2010). Феноменологический подход к исследованию ноодинамических переживаний: метод отдельных случаев и метод эмпирико-феноменологических исследований (на примере феномена прощения). Консультативная психология и психотерапия, 4, 48-67.

Мак-Каллоу, Дж. (2003). Лечение хронической депрессии. Санкт-Петербург: Речь.

Пуговкина, О. Д. (2014). Нарушения социального познания при депрессии: теоретические подходы, методы изучения и выделенные дефициты. Консультативная психология и психотерапия, 4 (22), 80-97.

Рикёр, П. (2004). Память. История. Забвение. Пер. с фр. И. И. Блауберг, И. С. Вдовиной, О. И. Мачульской, Г. М. Тавризян. Москва: Издательство гуманитарной литературы.

Родионова, А. А. (2007). Удовлетворение нравственной потребности в прощении как условие личностного роста (на примере семейных отношений). (Дис. канд. психол. наук). Тамбовский государственный университет им. Г. Р. Державина, Тамбов.

Сокур, А. В., \& Носенко, Е. Л. (2018). Готовність до пробачення як особистісний ресурс успішності подолання життєвих ускладнень. Науковий вісник Херсонського держсавного університету. Серія «Психологічні науки», 1 (2), 119-127.

Томильцева, Д. А. (2010). Опыт прощения: социально-философский анализ. (Автореф. дис. канд. филос. наук). Уральский государственный университет им. А. М. Горького, Екатеринбург.

Холмогорова, А. Б., \& Пуговкина, О. Д. (2015). Основные этапы и направления изучения когнитивных дисфункций при депрессиях. Медицинская психология в России: электронный научный журнал, 6 (35). Взято из http://mprj.ru (дата обращения: 09.10.2016 г.).

Чукова, А. С. (2011). Социально-психологические характеристики прощения как феномена межличностного общения. (Автореф. дис. канд. психол. наук). Саратовский государственный университет им. Н. Г. Чернышевского, Саратов.

Akhtar, S., Dolan, A., \& Barlow, J. (2017). Understanding the relationship between state forgiveness and psychological wellbeing: A qualitative study. Journal of Religion and Health, 56 (2), 450-463. doi: 10.1007/s10943-016-0188-9

Al-Mabuk, R. H., Enright, R. D., \& Cardis, P. A. (1995). Forgiveness education with parentally love-deprived late adolescents. Journal of Moral Education, 24 (4), 427-444.

Arendt, H. (1998). The Human Condition. Chicago: University of Chicago Press.

Barcaccia, B., Salvati, M., Pallini, S., Baiocco, R., Curcio, G., Mancini, F., \& Vecchio, G. M. (2020). Interpersonal Forgiveness and Adolescent Depression. The Mediational Role of Self-reassurance and Self-criticism. Journal of Child and Family Studies, 29 (2), 462-470. doi: 10.1007/s10826-019-01550-1

Baskin, T. W., \& Enright, R. D. (2004). Intervention Studies on Forgiveness: A Meta-Analysis. Journal of Counseling \& Development, 82 (1), 79-90. doi: 10.1002/j.1556-6678.2004.tb00288.x.

Bauer, L., Duffy, J., \& Fountain, E. (1992). Exploring self-forgiveness. Journal of Religion and Health, 31, 149-160.

Berry, J. W., Worthington, E. L., O'Connor, L. E., Parrott, L. I. \& Wade, N. G. (2005). Forgivingness, vengeful rumination, and affective traits. Journal of Personality, 73, 1-43. 
Brown, R. (2003). Measuring individual differences in the tendency to forgive: Construct validity and links with depression. Personality and Social Psychology Bulletin, 29 (6), 759-771. doi: $10.1177 / 0146167203029006008$

Davis, D. E., Hook, J. N., Van Tongeren, D. R., DeBlaere, C., Rice, K. G., \& Worthington, E. L. Jr. (2015). Making a decision to forgive. Journal of Counseling Psychology, 62, 280-288.

Davis, D. E., Yang, X., DeBlaere, C., McElroy, S. E., Van Tongeren, D. R., Hook, J. N. \& Worthington, E. J. (2016). The injustice gap. Psychology of Religion and Spirituality, 8, 175-184. doi: $10.1037 /$ rel0000042

Derogatis, L. R. (2001). Brief Symptom Inventory (BSI) - 18: Administration, scoring and procedures manual. Minneapolis, MN: NCS Pearson.

Derrida, J. (2005). On Cosmopolitanism and Forgiveness. London: Taylor \& Francis.

Elliott, B. A. (2011). Forgiveness therapy: a clinical intervention for chronic disease. Journal of Religion and Health, 50, 240-247. doi: 10.1007/s10943-010-9336-9

Emmons, R. A. (2000). Personality and forgiveness. In M. E. McCullough, K. I. Pargament, \& C. E. Thoresen, Forgiveness: Theory, research, and practice (pp. 156-175). New York: Guilford Press.

Enright, R. D. (2001). Forgiveness Is a Choice: A Step-by-Step Process for Resolving Anger and Restoring Hope. Washington, DC: American Psychological Association.

Enright, R. D. (1996). Human Development Study Group. Counseling within the forgiveness triad: On forgiving, receiving forgiveness, and self-forgiveness. Counseling and Values, 40, 107-126.

Enright, R. D., \& Fitzgibbons R. P. (2000). Helping clients forgive: An empirical guide for resolving anger and restoring hope. Washington, DC: American Psychological Association.

Fincham, F. D. (2000). The kiss of the porcupines: From attributing responsibility to forgiving. Personal Relationships, 7, 1-23.

Hall, J. H., Fincham, F. D. (2005) Self-forgiveness: The stepchild of forgiveness research. Journal of Social and Clinical Psychology, 24 (5), 621-637.

Harper, Q., Worthington, E. L., Griffin, B. J., Lavelock, C. R., Hook, J. N., Vrana, S. R., \& Greer, C. L. (2014). Efficacy of a workbook to promote forgiveness: a randomized controlled trial with university students. Journal of Clinical Psychology, 70 (12), 1158-1169. doi: 10.1002/jclp.22079

Heider, F. (1958). The Psychology of Interpersonal Relations. N.Y.: Wiley.

Hill, P. L., Allemand M., \& Burrow A. L. (2010). Identity development and forgivingness: Tests of basic relations and mediational pathways. Personality and Individual Differences, 49, 497-501.

Jankelevitch, V. (1996). Odpuštění. Praha: Mladá fronta.

Karremans, J. C., Van Lange, P. A., Ouwerkerk, J. W., \& Kluwer, E. S. (2003). When Forgiving Enhances Psychological Well-Being: The Role of Interpersonal Commitment. Journal of Personality and Social Psychology, 84 (5), 1011-1026.

Lijo, K. J. (2018). Forgiveness: Definitions, Perspectives, Contexts and Correlates. Journal of Psychology \& Psychotherapy, 8 (3), 342. doi: 10.4172/2161-0487.1000342

Macaskill, A., Maltby, J., \& Day, L. (2002). Forgiveness of self and others and emotional empathy. Journal of Social Psychology, 142 (5), 663-665.

Maltby, J., MacAskill, A., \& Day, L. (2001). Failure to forgive self and others: a replication and extension of the relationship between forgiveness, personality, social desirability and general health. Personality and Individual Differences, 30, 881-885. doi: 10.1016/S0191-8869(00)00080-5

Marks, M. J., Trafimow, D., Busche, L. K., \& Oates, K. N. (2013). A function of forgiveness: Exploring the relationship between negative mood and forgiving. SAGE Open, 3 (4), 1-9. doi: $10.1177 / 2158244013507267$

McCullough, M.E., Kurzban, R., \& Tabak, B. A. (2013). Cognitive systems for revenge and forgiveness. The Behavioral and Brain Sciences, 36 (1), 1-15. doi: 10.1017/S0140525X11002160

McCullough, M. E., \& Witvliet, C. V. (2002). The psychology of forgiveness. Handbook of Positive Psychology, 2, 446-455. 
McCullough, M. E., Worthington, E. L. Jr., \& Rachal, K. C. (1997). Interpersonal forgiving in close relationships. Journal of Personality and Social Psychology, 73, 321-336. Retrieved from http: //www.apa.org/pubs/journals/psp

Mullet, E., \& Girard, M. (2000). Developmental and cognitive points of view on forgiveness. In M. E. McCullough, K. I. Pargament, \& C. E. Thoresen. Forgiveness: Theory, research, and practice (pp. 111-132). New York: Guilford Press.

North, J. (1987). Wrongdoing and Forgiveness. Philosophy, 62 (242), 499-508.

Raj, P., Elizabeth, C. S., \& Padmakumari, P. (2016). Mental health through forgiveness: Exploring the roots and benefits. Cogent Psychology, 3 (1), 1153817. doi: 10.1080/23311908.2016.1153817.

Ricciardi, E., Rota, G., Sani, L., Gentili, C., Gaglianese, A., Guazzelli, M., Pietrini, P. (2013). How the brain heals emotional wounds: the functional neuroanatomy of forgiveness. Frontiers in Human Neuroscience, 7, 1-9. doi:10.3389/fnhum.2013.00839

Ross, J., Rachel, W., Boon, S. D., \& Stackhouse, M. R. D. (2018). Redefining unforgiveness: Exploring victims' experiences in the wake of unforgiven interpersonal transgressions. Deviant Behavior, 39(8), 1069-1081.

Sells, J. N., \& Hargrave, T. D. (1998). Forgiveness: a review of the theoretical and empirical literature. Journal of Family Therapy, 20, 21-36. doi: 10.1111/1467-6427.00066

Smedes, L. B. (1984). Forgive and forget: Healing the hurts we don't deserve. New York: Harper \& Row.

Strelan, P., \& Covic, T. (2006). A Review of Forgiveness Process Models and A Coping Framework to Guide Future Research. Journal of Social and Clinical Psychology, 25 (10), 1059-1085. doi: 10.1521 jscp.2006.25.10.1059

Tenklova, L., \& Slezackova, A. (2016). Differences between self-forgiveness and interpersonal forgiveness in relation to mental health. Journal of the Indian Academy of Applied Psychology, 42 (2), 281289.

Thompson, L. Y., Snyder, C. R., Hoffman, L., Michael, S. T., Rasmussen, H. N. et al. (2005). Dispositional forgiveness of self, thers, and situations. Journal of Personality, 73, 313-360. doi: 10.1111/j.1467-6494.2005.00311.x

Toussaint, L., \& Jorgensen, K. M. (2008). Inter-parental conflict, parent-child relationship quality, and adjustment in Christian adolescents: Forgiveness as a mediating variable. Journal of Psychology \& Christianity, 27 (4), 337-346. Retrieved from http: //caps.net/membership/publications/jpc

VanderWeele, T. J. (2018). Is Forgiveness a Public Health Issue? American Journal of Public Health, 108 (2), 189-190. doi: 10.2105/AJPH.2017.304210

Wade, N. G., \& Worthington, E. L. (2003). Overcoming interpersonal offenses: Is forgiveness the only way to deal with unforgiveness? Journal of Counseling \& Development, 81, 343-353. doi: 10.1002/j.1556-6678.2003.tb00261.x

Walton, E. (2005). Therapeutic forgiveness: developing a model for empowering victims of sexual abuse. Clinical Social Work Journal, 33, 193-207. doi: 10.1007/s10615- 005-3532-1

Wiesenthal, S. (1969). The Sunflower: On the Possibilities and Limits of Forgiveness. New York: Shocken Books.

Worthington, E. L., Davis, D., Hook, J., Van Tongeren, D., Gartner, A., Jennings, D., ... Greer, T. (2010). Forgiveness and religion: update and current status. A Journey through Forgiveness. Ed. by M. R. Maamri, N. Verbin, E. L. Worthington (pp. 49-57). Oxford: Inter-Disciplinary Press.

Worthington, E. L. Jr., Kurusu, T. A., Collins, W., Berry, J. W., Ripley, J. S., \& Baier, S. N. (2000). Forgiving usually takes time: A lesson learned by studying interventions to promote forgiveness. Journal of Psychology and Theology, 28 (1), 3-20. Retrieved from https://psycnet.apa.org/record/2000-15404-001

Worthington, E. L., \& Sandage, S. J. (2016). Forgiveness and Spirituality in Psychotherapy: A Relational Approach. Washington, DC: American Psychological Association.

Worthington, E. L. Jr., Witvliet, C. V. O., Pietrini, P., \& Miller, A. J. (2007). Forgiveness health, and well-being: A review of evidence for emotional versus decisional forgiveness, dispositional forgiveness, and reduced unforgiveness. Journal of Behavioral Medicine, 30, 291-302. 


\section{References}

Akhtar, S., Dolan, A., \& Barlow, J. (2017). Understanding the relationship between state forgiveness and psychological wellbeing: A qualitative study. Journal of Religion and Health. 2017, 56 (2), 450-463. doi: 10.1007/s10943-016-0188-9. (in English)

Al-Mabuk, R. H., Enright, R. D., \& Cardis, P. A. (1995). Forgiveness education with parentally love-deprived late adolescents. Journal of Moral Education, 24 (4), 427-444. (in English)

Arendt, H. (1998). The Human Condition. Chicago: University of Chicago Press. (in English)

Barcaccia, B., Salvati, M., Pallini, S., Baiocco, R., Curcio, G., Mancini, F., Vecchio, G. M. (2020). Interpersonal Forgiveness and Adolescent Depression. The Mediational Role of Self-reassurance and Selfcriticism. Journal of Child and Family Studies, 29 (2), 462-470. doi: 10.1007/s10826-019-01550-1. (in English)

Baskin, T. W., \& Enright, R. D. (2004). Intervention Studies on Forgiveness: A Meta-Analysis. Journal of Counseling \& Development, 82 (1), 79-90. doi: 10.1002/j.1556-6678.2004.tb00288.x. (in English)

Bauer, L., Duffy, J., \& Fountain, E. (1992). Exploring self-forgiveness. Journal of Religion and Health, 31, 149-160. (in English)

Berry, J. W., Worthington, E. L., O’Connor, L. E., Parrott, L. I. \& Wade, N. G. (2005). Forgivingness, vengeful rumination, and affective traits. Journal of Personality, 73, 1-43. (in English)

Bolshunova, N. Y. (2017). Proshcheniye kak dukhovno-nravstvennoye yavleniye i psikhologicheskiy fenomen [Forgiveness as a spiritual and moral phenomenon and a psychological phenomenon]. Chelovek $i$ mir [Man and the world], 1 (1), 201-218. (in Russian)

Brown, R. (2003). Measuring individual differences in the tendency to forgive: Construct validity and links with depression. Personality and Social Psychology Bulletin, 29 (6), 759-771. doi: 10.1177/0146167203029006008. (in English)

Chukova, A. S. (2011). Sotsialno-psikhologicheskiye kharakteristiki proshcheniya kak fenomena mezhlichnostnogo obshcheniya [Socio-psychological characteristics of forgiveness as a phenomenon of interpersonal communication]. (Master's thesis). Saratovskiy gosudarstvennyy universitet in. N. G. Chernyshevskogo, Saratov. (in Russian)

Davis, D. E., Hook, J. N., Van Tongeren, D. R., DeBlaere, C., Rice, K. G., \& Worthington, E. L. Jr. (2015). Making a decision to forgive. Journal of Counseling Psychology, 62, 280-288. (in English)

Davis, D. E., Yang, X., DeBlaere, C., McElroy, S. E., Van Tongeren, D. R., Hook, J. N. \& Worthington, E. J. (2016). The injustice gap. Psychology of Religion and Spirituality, 8, 175-184. doi:10.1037/rel0000042. (in English)

Derogatis, L. R. (2001). Brief Symptom Inventory (BSI) - 18: Administration, scoring and procedures manual. Minneapolis, MN: NCS Pearson. (in English)

Derrida, J. (2005). On Cosmopolitanism and Forgiveness. London: Taylor \& Francis. (in English)

Elliott, B. A. (2011). Forgiveness therapy: a clinical intervention for chronic disease. Journal of Religion and Health, 50, 240-247. doi: 10.1007/s10943-010-9336-9. (in English)

Emmons, R. A. (2000). Personality and forgiveness. In M. E. McCullough, K. I. Pargament, \& C. E. Thoresen. Forgiveness: Theory, research, and practice (pp. 156-175). New York: Guilford Press. (in English)

Enright, R. D. (2001). Forgiveness Is a Choice: A Step-by-Step Process for Resolving Anger and Restoring Hope. Washington, DC: American Psychological Association. (in English)

Enright, R. D. (1996). Human Development Study Group. Counseling within the forgiveness triad: On forgiving, receiving forgiveness, and self-forgiveness. Counseling and Values, 40, 107-126. (in English)

Enright, R. D., \& Fitzgibbons R. P. (2000). Helping clients forgive: An empirical guide for resolving anger and restoring hope. Washington, DC: American Psychological Association. (in English)

Fincham, F. D. (2000). The kiss of the porcupines: From attributing responsibility to forgiving. Personal Relationships, 7, 1-23. (in English) 
Gassin, E. A. (1999). Psikhologiya proshcheniya [The psychology of forgiveness]. Voprosy psikhologii [Psychology issues], 4, 93-104. (in Russian)

Gassin, E. (2003). Pravoslaviye i problema proshcheniya [Orthodoxy and the problem of forgivenes]. Moskovskiy psikhoterapevticheskiy zhurnal [Moscow psychotherapeutic journal], 3, 166-186. (in Russian)

Hall, J. H., \& Fincham, F. D. (2005) Self-forgiveness: The stepchild of forgiveness research. Journal of Social and Clinical Psychology, 24 (5), 621-637. (in English)

Harper, Q., Worthington, E. L., Griffin, B. J., Lavelock, C. R., Hook, J. N., Vrana, S. R., \& Greer, C. L. (2014). Efficacy of a workbook to promote forgiveness: a randomized controlled trial with university students. Journal of Clinical Psychology, 70 (12), 1158-1169. doi: 10.1002/jclp.22079. (in English)

Heider, F. (1958). The Psychology of Interpersonal Relations. N.Y.: Wiley. (in English)

Hill, P. L., Allemand M., \& Burrow A. L. (2010). Identity development and forgivingness: Tests of basic relations and mediational pathways. Personality and Individual Differences, 49, 497-501. (in English)

Jankelevitch, V. (1996). Odpuštění. Praha: Mladá fronta. (in Čeština)

Karremans, J. C., Van Lange, P. A., Ouwerkerk, J. W., \& Kluwer, E. S. (2003). When Forgiving Enhances Psychological Well-Being: The Role of Interpersonal Commitment. Journal of Personality and Social Psychology, 84 (5), 1011-1026. (in English)

Kholmogorova, A. B., Pugovkina, O. D. (2015). Osnovnyye etapy i napravleniya izucheniya kognitivnykh disfunktsiy pri depressiyakh [The main stages and directions of the study of cognitive dysfunctions in depression]. Meditsinskaya psikhologiya v Rossii: elektronnyy nauchnyy zhurnal [Medical psychology in Russia: electronic scientific journal], 6 (35). Retrieved from http://mprj.ru (09.10.2016 g.). (in Russian)

Kononova, A. P., \& Pugovkina, O. D. (2018). Validizatsiya oprosnika «Sklonnost k proshcheniyu i ustanovki po otnosheniyu $\mathrm{k}$ proshcheniyu prostupkov» na rossiyskoy vyborke [Validation of the questionnaire «Propensity for forgiveness and attitudes towards forgiveness of wrongdoing» in a Russian sample]. Konsultativnaya psikhologiya i psikhoterapiya [Counseling psychology and psychotherapy], 26 (4),

27-45. doi: 10.17759/cpp.2018260403. (in Russian)

Krivtsova, S. V. (2010). Fenomenologicheskiy podkhod k issledovaniyu noodinamicheskikh perezhivaniy: metod otdelnykh sluchayev i metod empiriko-fenomenologicheskikh issledovaniy (na primere fenomena proshcheniya) [A phenomenological approach to the study of noodynamic experiences: the method of individual cases and the method of empirical-phenomenological research (on the example of the phenomenon of forgiveness)]. Konsultativnaya psikhologiya i psikhoterapiya [Counseling psychology and psychotherapy], 4, 48-67. (in Russian)

Lijo, K. J. (2018). Forgiveness: Definitions, Perspectives, Contexts and Correlates. Journal of Psychology \& Psychotherapy, 8 (3), 342. doi: 10.4172/2161-0487.1000342. (in English)

Macaskill, A., Maltby, J., \& Day, L. (2002). Forgiveness of self and others and emotional empathy. Journal of Social Psychology, 142 (5), 663-665. (in English)

Mak-Kallou, Dzh. (2003). Lecheniye khronicheskoy depressii [Chronic depression treatment]. St. Petersburg: Rech. (in Russian)

Maltby, J., MacAskill, A., \& Day, L. (2001). Failure to forgive self and others: a replication and extension of the relationship between forgiveness, personality, social desirability and general health. Personality and Individual Differences, 30, 881-885. doi: 10.1016/S0191-8869(00)00080-5. (in English)

Marks, M. J., Trafimow, D., Busche, L. K., \& Oates, K. N. (2013). A function of forgiveness: Exploring the relationship between negative mood and forgiving. SAGE Open, 3 (4), 1-9. doi: 10.1177/2158244013507267. (in English)

McCullough, M. E., Kurzban, R., \& Tabak, B. A. (2013). Cognitive systems for revenge and forgiveness. The Behavioral and Brain Sciences, 36 (1), 1-15. doi: 10.1017/S0140525X11002160. (in English)

McCullough, M. E., Witvliet, C. V. (2002). The psychology of forgiveness. Handbook of Positive Psychology, 2, 446-455. (in English) 
McCullough, M. E., Worthington, E. L. Jr., \& Rachal, K. C. (1997). Interpersonal forgiving in close relationships. Journal of Personality and Social Psychology, 73, 321-336. Retrieved from http: //www.apa.org/pubs/journals/psp. (in English)

Mullet, E., \& Girard, M. (2000). Developmental and cognitive points of view on forgiveness. In M. E. McCullough, K. I. Pargament, \& C. E. Thoresen, Forgiveness: Theory, research, and practice (pp. 111-132). New York: Guilford Press. (in English)

North, J. (1987). Wrongdoing and Forgiveness. Philosophy, 62 (242), 499-508. (in English)

Pugovkina, O. D. (2014). Narusheniya sotsialnogo poznaniya pri depressii: teoreticheskiye podkhody, metody izucheniya i vydelennyye defitsity [Social cognition disorders in depression: theoretical approaches, research methods and highlighted deficiencies]. Konsultativnaya psikhologiya i psikhoterapiya [Counseling psychology and psychotherapy], 4 (22), 80-97. (in Russian)

Raj, P., Elizabeth, C. S., Padmakumari, P. (2016). Mental health through forgiveness: Exploring the roots and benefits. Cogent Psychology, 3 (1), 1153817. doi: 10.1080/23311908.2016.1153817. (in English)

Ricciardi, E., Rota, G., Sani, L., Gentili, C., Gaglianese, A., Guazzelli, M., \& Pietrini, P. (2013). How the brain heals emotional wounds: the functional neuroanatomy of forgiveness. Frontiers in Human Neuroscience, 7, 1-9. doi:10.3389/fnhum.2013.00839. (in English)

Rikor, P. (2004). Pamyat. Istoriya. Zabveniye [Memory, History, Oblivion]. Moscow: Izdatelstvo gumanitarnoy literatury. (in Russian)

Rodionova, A. A. (2007). Udovletvoreniye nravstvennoy potrebnosti $\mathrm{v}$ proshchenii kak usloviye lichnostnogo rosta (na primere semeynykh otnosheniy) [Meeting the moral need for forgiveness as a condition for personal growth (on the example of family relations)]. (Master's thesis). Tambovskiy gosudarstvenny universitet in. J. K. Derzhavina, Tambov. (in Russian)

Ross, J., Rachel, W., Boon, S. D., \& Stackhouse, M. R. D. (2018). Redefining unforgiveness: Exploring victims' experiences in the wake of unforgiven interpersonal transgressions. Deviant Behavior, 39(8), 1069-1081. (in English)

Sells, J. N., \& Hargrave, T. D. (1998). Forgiveness: a review of the theoretical and empirical literature. Journal of Family Therapy, 20, 21-36. doi: 10.1111/1467-6427.00066. (in English)

Smedes, L. B. (1984). Forgive and forget: Healing the hurts we don't deserve. New York: Harper \& Row. (in English)

Sokur, A. V., Nosenko, E. L. (2018). Hotovnist do probachennya yak osobystisnyy resurs uspishnosti podolannya zhyttyevykh uskladnen [Willingness to forgive as a personal resource for success in overcoming life's difficulties]. Naukovyi visnyk Khersonskoho derzhavnoho universytetu. Seriia «Psykholohichni nauky» [Scientific Bulletin of Kherson State University. Psychological Sciences Series], 1 (2), 119-127. (in Ukrainian)

Strelan, P., \& Covic, T. (2006). A Review of Forgiveness Process Models and A Coping Framework to Guide Future Research. Journal of Social and Clinical Psychology, 25 (10), 1059-1085. doi: 10.1521/jscp.2006.25.10.1059. (in English)

Tenklova, L., \& Slezackova, A. (2016). Differences between self-forgiveness and interpersonal forgiveness in relation to mental health. Journal of the Indian Academy of Applied Psychology, 42 (2), 281289. (in English)

Thompson, L. Y., Snyder, C. R., Hoffman, L., Michael, S. T., Rasmussen, H. N. et al. (2005). Dispositional forgiveness of self, thers, and situations. Journal of Personality, 73, 313-360. DOI: 10.1111/j.1467-6494.2005.00311.x. (in English)

Tomiltseva, D. A. (2010). Opyt proshcheniya: sotsialno-filosofskiy analiz [The Forgiveness Experience: A Socio-Philosophical Analysis]. (Master's thesis). Uralskiy gosudarstvennyy universitet in. A. M. Gorkogo, Yekaterinburg. (in Russian)

Toussaint, L., \& Jorgensen, K. M. (2008). Inter-parental conflict, parent-child relationship quality, and adjustment in Christian adolescents: Forgiveness as a mediating variable. Journal of Psychology \& Christianity, 27 (4), 337-346. Retrieved from http: //caps.net/membership/publications/jpc. (in English)

VanderWeele, T. J. (2018). Is Forgiveness a Public Health Issue? American Journal of Public Health, 108 (2), 189-190. doi: 10.2105/AJPH.2017.304210. (in English) 
Wade, N. G., \& Worthington, E. L. (2003). Overcoming interpersonal offenses: Is forgiveness the only way to deal with unforgiveness? Journal of Counseling \& Development, 81, 343-353. doi: 10.1002/j.1556-6678.2003.tb00261.x. (in English)

Walton, E. (2005). Therapeutic forgiveness: developing a model for empowering victims of sexual abuse. Clinical Social Work Journal, 33, 193-207. doi: 10.1007/s10615- 005-3532-1. (in English)

Wiesenthal, S. (1969). The Sunflower: On the Possibilities and Limits of Forgiveness. New York: Shocken Books. (in English)

Worthington, E. L., Davis, D., Hook, J., Van Tongeren, D., Gartner, A., Jennings, D., Greer, C., Greer, T. (2010). Forgiveness and religion: update and current status. A Journey through Forgiveness. Ed. by M. R. Maamri, N. Verbin, E. L. Worthington (pp. 49-57). Oxford: Inter-Disciplinary Press. (in English)

Worthington, E. L. Jr., Kurusu, T. A., Collins, W., Berry, J. W., Ripley, J. S., \& Baier, S. N. (2000). Forgiving usually takes time: A lesson learned by studying interventions to promote forgiveness. Journal of Psychology and Theology, 28 (1), 3-20. Retrieved from: https://psycnet.apa.org/record/2000-15404-001. (in English)

Worthington, E. L., Sandage, S. J. (2016). Forgiveness and Spirituality in Psychotherapy: A Relational Approach. Washington, DC: American Psychological Association. (in English)

Worthington, E. L. Jr., Witvliet, C. V. O., Pietrini, P., \& Miller, A. J. (2007). Forgiveness health, and well-being: A review of evidence for emotional versus decisional forgiveness, dispositional forgiveness, and reduced unforgiveness. Journal of Behavioral Medicine, 30, 291-302. (in English)

Zlyvkov, V. L., Lukomska, S. O. (2017). Proshchennia inshykh i proshchennia sebe v konteksti podolannia osobystistiu kryzovykh sytuatsii [Forgiveness of others and forgiveness of oneself in the context of overcoming personal crisis situations]. Teoretychni i prykladni problemy psykholohii [Theoretical and applied problems of psychology], 2, 103-112. (in Ukrainian) 